Research note

\title{
First record of Karualona penuelasi (Cladocera: Anomopoda: Chydoridae) from Colombia
}

\author{
Primer registro de Karualona penuelasi (Cladocera: Anomopoda: Chydoridae) de Colombia \\ Juan M. Fuentes-Reines ${ }^{a}{ }^{a}$, Lourdes M.A. Elmoor-Loureiro ${ }^{b}$ \\ a Grupo de investigación en Biodiversidad y Conservación de Ecosistemas, Calle 25, Núm. 2-124, Santa Marta, Magdalena, Colombia

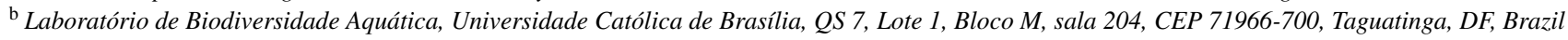

Received 7 November 2014; accepted 2 June 2015

Available online 10 November 2015

\begin{abstract}
The cladoceran Karualona penuelasi (Dumont \& Silva-Briano, 2000) (Anomopoda: Chydoridae) was found associated with the aquatic macrophytes Eichhornia crassipes in Cerro de San Antonio Swamp, Magdalena Department, Colombia. This record represents the first one of the species in Colombia and in South America. Comments on Karualona muelleri (Richard, 1897) and Karualona karua (King, 1853) are included.

All Rights Reserved (C) 2015 Universidad Nacional Autónoma de México, Instituto de Biología. This is an open access item distributed under the Creative Commons CC License BY-NC-ND 4.0.

Keywords: Cladocera; Swamp; Colombia; New record

\section{Resumen}

El cladócero Karualona penuelasi [Dumont y Silva-Briano, 2000] (Anomopoda: Chydoridae) fue encontrado asociado con la macrofita acuática Eichhornia crassipes en la ciénaga Cerro de San Antonio, Departamento del Magdalena, Colombia. Este registro representa el primero de la especie en Colombia y en Sudamérica. Se incluyen comentarios sobre Karualona muelleri [Richard, 1897] y Karualona karua [King, 1853].

Derechos Reservados (C) 2015 Universidad Nacional Autónoma de México, Instituto de Biología. Este es un artículo de acceso abierto distribuido bajo los términos de la Licencia Creative Commons CC BY-NC-ND 4.0.
\end{abstract}

Palabras clave: Cladocera; Ciénaga; Colombia; Registro nuevo

According to Van Damme, Maiphae, and Sa-Ardrit (2013), the genus Karualona comprises 7 species: K. karua (King, 1853), K. muelleri (Richard, 1897), K. iberica (Alonso \& Pretus, 1989), K. alsafadi (Dumont \& Brancelj, 1994), K. penuelasi (Dumont \& Silva-Briano, 2000), K. socotrana (Dumont \& SilvaBriano, 2000), and K. serrulata (Van Damme et al., 2013). Of these species, $K$. muelleri and $K$. penuelasi surely occur in the Neotropics, while the presumed records of $K$. karua are doubtful (Sinev \& Hollwedel, 2005). Apparently, more species of this

\footnotetext{
* Corresponding author.

E-mail address: juanmanuelfuentesreines@yahoo.com

(J.M. Fuentes-Reines).

Peer Review under the responsibility of Universidad Nacional Autónoma de
} México. genus are present in the tropics, but they are waiting for their formal description (Kotov, Van Damme, et al., 2013).

The study of composition and distribution of the genus Karualona in Colombia is still lagging. Up to now, the single valid species known to exist in Colombia is K. muelleri (Fuentes, Zoppi-de Roa, Gámez, Morón, \& López, 2012). Pearse (1916) reported Alonella karua in the Magdalena Department, but this record probably refers to $K$. muelleri, $K$. penuelasi or an undescribed species. Since no figures or description were presented in Pearse's paper, the specific identity cannot be confirmed. A recent biological survey of the aquatic fauna of a swamp of southern Magdalena yielded 2 parthenogentic females of $K$. penuelasi (Dumont \& Silva-Briano, 2000), which was originally described from Peñuelas Dam, Aguascalientes, Mexico. This study reports the first Colombian record of $K$. penuelasi, 

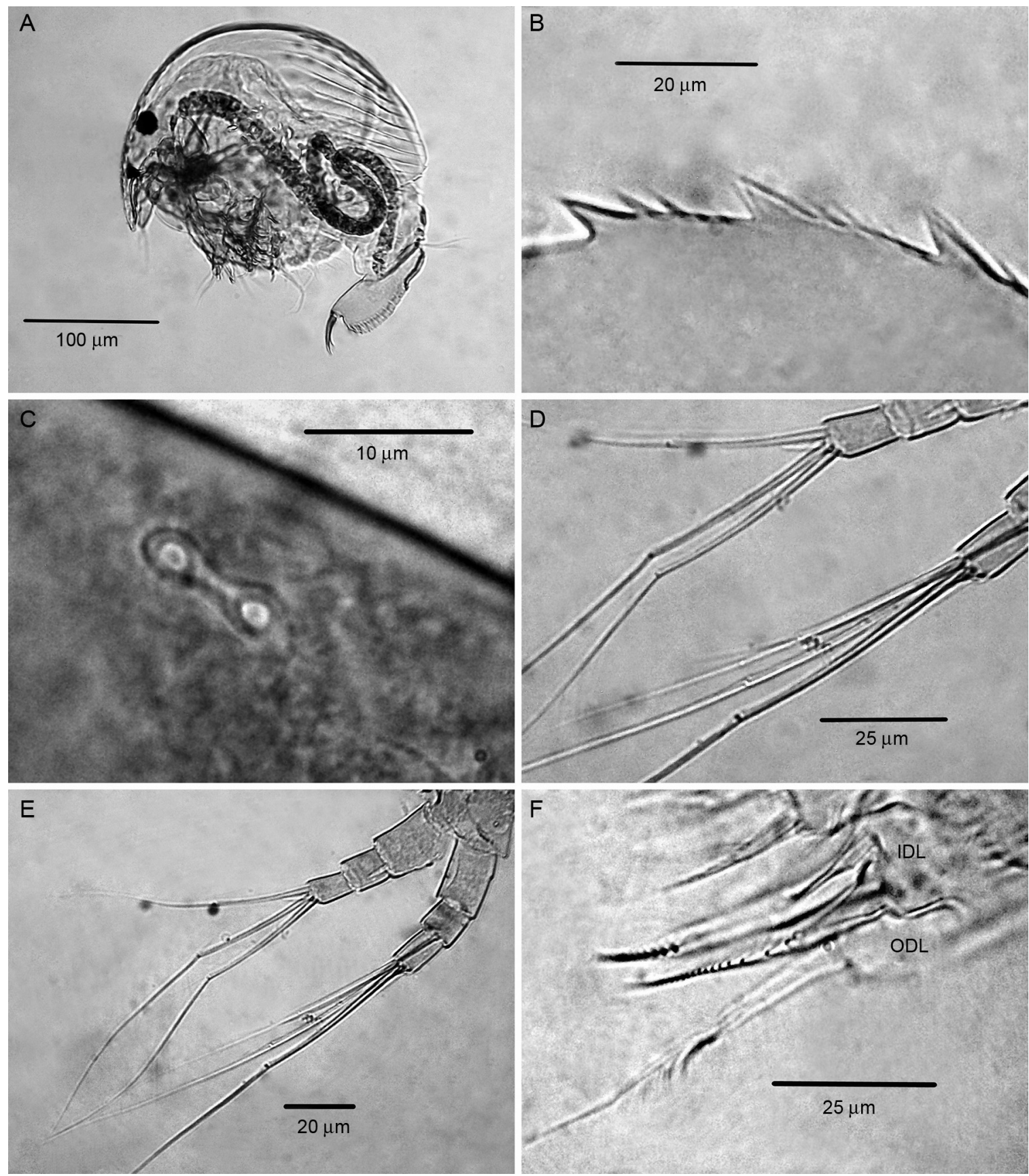

Figure 1. Karualona penuelasi, parthenogenetic female: (A) habitus; (B) posteroventral angle of valve; (C) head pores; (D) distal portion of the endopod and exopod of antenna; (E) antenna; (F) limb I.

and indicates an important expansion of the known distributional range of this species, from Central America to South America.

Samples were taken from the aquatic vegetation in Cerro de San Antonio Swamp, Magdalena Department $\left(10^{\circ} 19^{\prime} 30^{\prime \prime} \mathrm{N}\right.$, $74^{\circ} 52^{\prime} 05^{\prime \prime} \mathrm{W}$ ), Colombia in June 2004. Water samples were collected using a $65 \mathrm{~L}$ bucket. Samples were filtered with a standard zooplankton net ( $45 \mu \mathrm{m}$ mesh) and preserved in $70 \%$ ethanol. The specimens were dissected and the taxonomically relevant appendages were mounted in semi-permanent slides that were deposited in the Museo de Colecciones Biológicas of the Universidad del Atlántico, Barranquilla-Atlántico, Colombia (UARC210M-UARC214M). The appendages were photographed using a Kodak Easy Share C140 digital camera adapted to a compound microscope. The specimens were measured in lateral position, from the head to the posterior margin of the valves. Identifications were according with Dumont and Silva-Briano (2000), Elías-Gutiérrez et al. (2008) and Van Damme et al. (2013).

Karualona penuelasi was found associated with the aquatic macrophyte Eichhornia crassipes (Mart.) Solms. The analyzed specimens showed the typical characteristics of $K$. penuelasi. Body oval (Fig. 1A); body length from head to posterior part of valve ranging from 0.25 to $0.28 \mathrm{~mm}(n=2$, mean $=0.27 \mathrm{~mm})$; length:height ratio 1.4 , sculpture of valve with 10 striae 

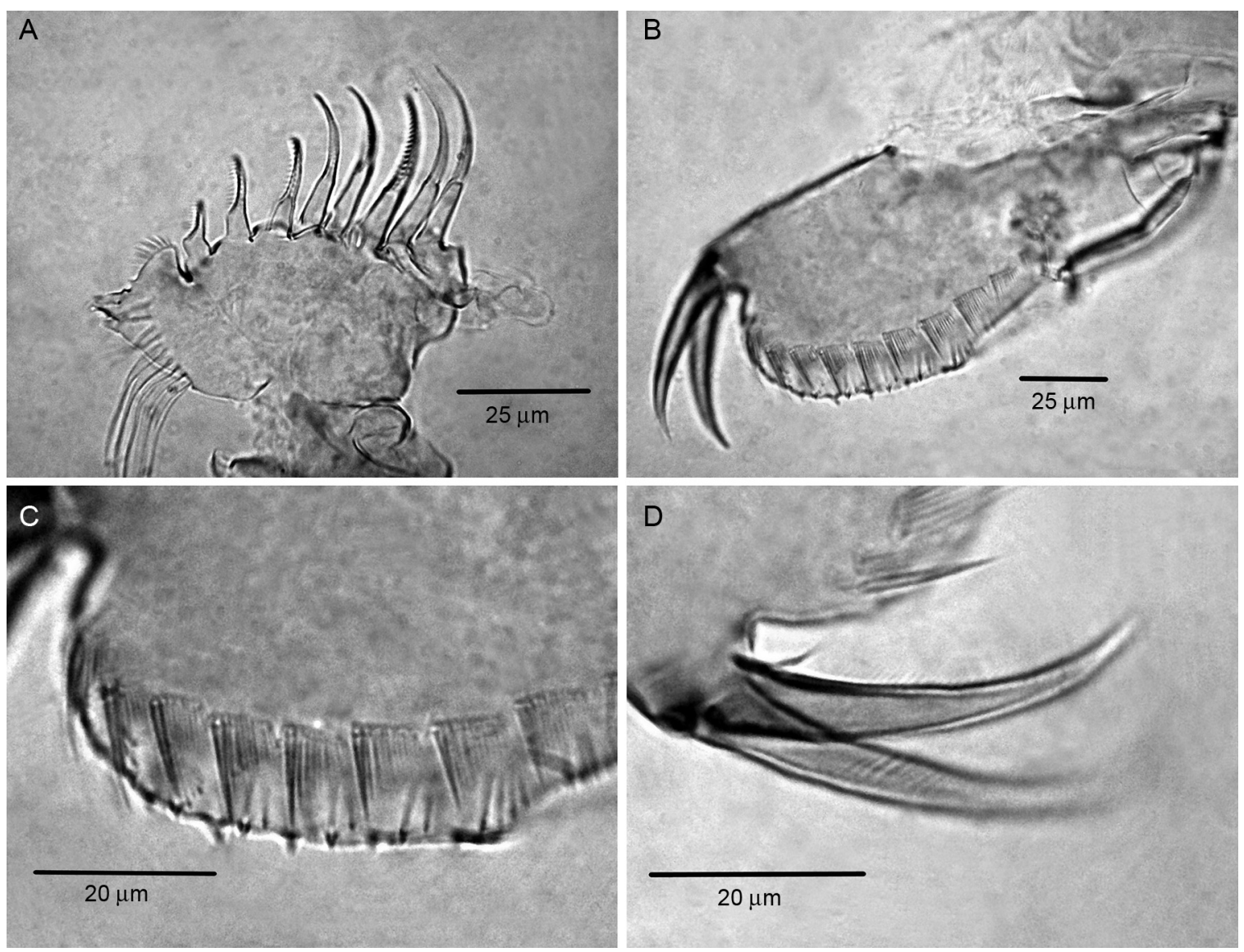

Figure 2. Karualona penuelasi, parthenogenetic female: (A) limb II; (B) postabdomen; (C) lateral fascicles of postabdomen; (D) postadbominal claw.

(Fig. 1A); postero-ventral corner of valve with 3-4 setules between each pair of denticles (Fig. 1B); 2 main head pores; connected, as the genus (Fig. 1C); antenna II with setal formula $0-1-3 / 0-0-3$; all apical setae of antennal exopod of same thickness (Fig. 1D and E). Inner distal lobe (IDL) of trunk limb I with 3 setae; inner and outer setae of different size; outer distal lobe (ODL) of limb I with long seta (Fig. 1F); all scrapers on trunk of limb II with denticles of equal thickness (Fig. 2A); postabdomen robust, lateral fascicles thin, short; distal setules length of lateral fascicles of postabdomen/postabdominal claw base width ratio about 1.5 (Fig. 2B and C); postabdominal claw with fine pecten and small basal spine on base (Fig. 2D).

Karualona penuelasi is considered as a Neotropical species (Dumont \& Silva-Briano, 2000; Kotov, Forró, Korovchinsky, \& Petrusek, 2013; Van Damme et al., 2013) and most closely resembles $K$. muelleri and $K$. karua in the body shape and valve sculpture, but these species can be separated by the following characters: (1) setae on the antennal exopod are of the same thickness in K. penuelasi and K. karua (Dumont \& Silva-Briano, 2000; figs. 2 and 3) while in K. muelleri the longest seta is thicker than the others (Sinev \& Hollwedel, 2005; fig. 19); (2) lateral fascicles of postabdomen are thin and short in $K$. penuelasi (Dumont \& Silva-Briano, 2000; fig. 15-2, present paper, Fig. 2C) while in K. muelleri and K. karua they are thick and long (Sinev \& Hollwedel, 2005; figs. 20-22; Dumont \& Silva-Briano, 2000; fig. 15-5); (3) length of distal setules in lateral fascicles located on the postabdomen/diameter of postabdominal claw base ratio about 1.5 in K. penuelasi (Dumont \& Silva-Briano, 2000; fig. 15-2, present paper, Fig. 2C) while in K. muelleri and K. karua about 2 (Sinev \& Hollwedel, 2005; figs. 20-22; Dumont \& Silva-Briano, 2000; fig. 15-5); (4) outer and inner setae of IDL of limb I of different size in $K$. penuelasi and K. karua (Dumont \& Silva-Briano, 2000; fig. 6-2; 6-3, present paper, Fig. $1 \mathrm{~F}$ ) while in $K$. muelleri both setae are of the same size (Sinev \& Hollwedel, 2005; fig. 25); (5) all scrapers of limb II with denticles of equal thickness in $K$. penuelasi and $K$. karua (Dumont \& Silva-Briano, 2000; figs. 9-2, 9-3, present paper, Fig. 2A) while in $K$. muelleri scrapers 3 and 6 present more robust denticles (Sinev \& Hollwedel, 2005; fig. 26); (6) length of scrapers 1 and 2 of limb II of the same size in K. penuelasi and K. muelleri (Dumont \& Silva-Briano, 2000; fig. 9-3; Sinev \& Hollwedel, 2005; fig. 26; present paper, Fig. 2A) of different in size in K. karua (Dumont \& Silva-Briano, 2000; fig. 9-2); (7) postero-ventral corner of valve with 1-4 setules between each pair of denticles in K. penuelasi (Dumont \& Silva-Briano, 2000; fig. 5-1, Sinev \& Hollwedel, 2005: 100; present paper, Fig. 1B), 5-7 in K. muelleri (Sinev \& Hollwedel, 2005; fig. 17) and 4 in K. karua (Dumont \& Silva-Briano, 2000; fig. 5-2).

In the surveyed area, $K$. penuelasi was found associated to the aquatic vegetation, where water temperature was $32.6^{\circ} \mathrm{C}$, conductivity $260 \mu \mathrm{S} \mathrm{m}^{-1}$, total dissolved solids 120 , and $\mathrm{pH}$ 8.4. The presence of $K$. penuelasi in nearby waters seems 
very likely, so a wider distribution in South America might be expected.

We are very grateful to Dr. Silva-Briano and Dr. Sinev Artem for their valuable consultations. This study was financially supported by the Fundación para la Participación, Capacitación y la Investigación Social "FUPARCIS".

\section{References}

Dumont, H. J., \& Silva-Briano, M. (2000). Karualona n. gen. (Anomopoda, Chydoridae), with a description of two new species, and a key to all known species. Hydrobiologia, 435, 61-82.

Elías-Gutiérrez, M., Suárez, E., Gutiérrez, M., Silva, M., Granados, J., \& Garfia, T. (2008). Cladocera y Copepoda de las aguas continentales de México. México D.F.: Comisión Nacional para el Conocimiento y Uso de la Biodiversidad, Facultad de Estudios Superiores-Iztacala (UNAM), El Colegio de la Frontera Sur

Fuentes, J., Zoppi-de Roa, E., Gámez, D., Morón, E., \& López, C. (2012). Conocimiento de la fauna de Cladocera (Crustacea: Branchiopoda) de la ciénaga Grande de Santa Marta, Colombia. Boletín de Investigaciones Marinas y Costeras, 41, 121-167.

Kotov, A., Forró, A. L., Korovchinsky, N. M., \& Petrusek, A. (2013). World checklist of freshwater Cladocera species. World Wide Web electronic publication. Retrieved from: http://fada.biodiversity.be/group/show/17

Kotov, A. A., Van Damme, K., Bekker, E. I., Siboualipha, S., Silva-Briano, M., Adabache-Ortiz, A., et al. (2013). Cladocera (Crustacea: Branchiopoda) of Vientiane province and municipality, Laos. Journal of Limnology, 72(S2), 81-108.

Pearse, A. S. (1916). An account of the Crustacea collected by the Walker Expedition to Santa Marta Colombia. Proceedings of the United States National Museum, 49, 530-556.

Sinev, A. Y., \& Hollwedel, W. (2005). Translocation of Alona muelleri Richard, 1897 into the genus Karualona Dumont and Silva-Briano, 2000 (Branchiopoda: Anomopoda: Chydoridae). Arthropoda Selecta, 14, 93-101.

Van Damme, K., Maiphae, P., \& Sa-Ardrit, P. (2013). Inland swamps in South East Asia harbour hidden cladoceran diversities: species richness and the description of new paludal Chydoridae (Crustacea: Branchiopoda: Cladocera) from Southern Thailand. Journal of Limnology, 72(S2), 174-208. 